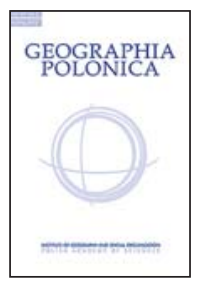

\title{
SPATIAL DIVERSITY OF TOURIST FACILITIES IN THE SILESIAN BESKID MOUNTAINS IN POLAND
}

\section{Anna Żemła-Siesicka ${ }^{1}$ (D) - Viacheslav Andreychouk ${ }^{2}$ (iD) Urszula Myga- -Piątek ${ }^{1}$}

\author{
${ }^{1}$ Faculty of Natural Sciences \\ University of Silesia \\ Będzińska 60, Sosnowiec: Poland \\ e-mails: anna.zemla-siesicka@us.edu.pl (corresponding author) • urszula.myga-piatek@us.edu.pl \\ ${ }^{2}$ Faculty of Geography and Regional Studies \\ University of Warsaw \\ Krakowskie Przedmieście 30, 00-927 Warszawa: Poland \\ e-mail: w.andrejczuk2@uw.edu.pl
}

\begin{abstract}
This article proposes a method of the assessment of distribution of tourist facilities. The main aim of presented study is to assess a spatial density of tourist elements. The evaluation of the distribution of tourist facilities in the landscape allows to indicate overloaded areas. The second purpose is the proposition of an indicator measuring the landscape saturation of tourist facilities, i.e. density index developed by the authors. The index, referred to river basin, is based on the ratio of the area of the tourist facilities to the total area of the unit. For the purposes of calculation, the authors developed a framework for the classification of tourist facilities based on its spatial character. The method was examined in the Silesian Beskid mountain range and can be applied in similar mountain areas.
\end{abstract}

\section{Key words}

Silesian Beskid - tourist landscape - tourist facilities - human impact on landscape - index of tourist facilities density - impact of tourist facilities on landscape

\section{Introduction}

Increasingly often, tourism develops spontaneously and puts pressure on the natural environment and on landscape The effects of tourism, and especially of mass tourism, and its global scale are currently seen as some of the most significant manifestations of human pressure on natural systems (Cohen, 1978; Myga-Piatek, 2011). The landscape is subject to pressure from expanding tourist infrastructure and tourist traffic, which causes urbanisation in tourist destinations and lasting spatial transformations (Mullins, 
2009; Boori, Voženílek, \& Choudhary, 2015; Petrikovičová, Krogmann, Fialová \& Svorad, 2019).

Because of the dynamic development of tourist facilities, the material, physiognomic and symbolic values of the landscape can be damaged or lost. Very often, conflicts arise at the intersection of economics, sociocultural issues, environmental protection and resource usage. (Inskeep, 1987; Burns, 2004; Pawłowski, 2009). Conflicts between investors and environmentalists related to the protection of areas of special environmental value, such as mountainous areas, are often widely discussed in scientific works (e.g. Butler, 1980, 1996; Barker, 1982; Stalski, 1986; Agarwal, 1998; Sołtys, 2009; Partyka, 2010; Myga-Piatek, 2011, 2016; Włodarczyk, 2011, 2014; Duffy, 2014; Stoffelen \& Vanneste, 2015) and receive coverage in the media (i.e. WWF post concerning plans for new skiing areas in the region around the Carpathian Mountains and the Balkans, Ski area plans threaten Europe's last untouched forests, 2009). In Poland, for example, there is much controversy surrounding the construction of new ski lifts and ski runs, such as the construction of a ski station in Wierchomla (Okrasiński, 2012), the expansion of the ski resort on the Pilsko mountain (Ślusarczyk \& Bożek, 2006), and the construction of large hotel complexes in the Beskid and Karkonosze mountains. Striking examples of such developments are the large Gołębiewski Hotel in Karpacz (Żemła \& Żemła-Siesicka, 2010) and the recent construction of an enormous hotel with architecture resembling a castle on an island inside the Natura 2000 area in Stobnica, in the Notecka Forest (Zamek na obszarze Natura 2000).

As a result of the particular sensitivity of the academic community to this issue and its importance, numerous articles on the relationships between tourist activities and landscapes have been published (Gunn, 1979; Baranowska-Janota \& Kozłowski, 1984; Łajczak, 1994; Gormsen, 1997; Terkenli, 2002; Mika, 2004; Myga-Piątek, 2006, 2016; Gkoltsiou \& Terkenli, 2008; Myga-Piątek \& Jankowski,
2009; Andrejczuk, 2010; Pietrzak, 2010; Jansen-Verbeke \& McKercher, 2013). There has also been a lot of work undertaken so far on the influence of tourism on the physiognomic aspects of the landscape (i.e. Wyrzykowski, 1991; Chmielewski, 2012; Gkoltsiou \& Terkenli, 2012; Nita, Myga-Piątek, \& Absalon, 2015; Chmielewski, Śleszyński, Chmielewski, \& Kułak, 2018), but they have not attempted an objective approach to spatial issues in the study of tourist infrastructure. The quantity, quality and diversity of types of existing elements has so far been neglected.

Considering that the excessively intensive development (in terms of the number of tourist facilities) may lead to the negative changes of the landscape properties which attracted the tourists in the first place, it is important to identify areas where the density of existing elements is high. In such areas, further development may disturb the visual integrity of the landscape. The indication of the intensity of tourist facility development is important for the planning of further investments, especially in the case of areas with important natural and landscape values, such as mountainous areas.

This article closes the research gap in the spatial analyses of tourist infrastructure by proposing a method of the assessment of distribution of tourist facilities. The main aim of presented study is to assess a spatial density of tourist elements. The evaluation of the distribution of tourist facilities in the landscape allows to indicate overloaded areas. The second purpose is the proposition of an indicator measuring the landscape saturation of tourist facilities, i.e. density index developed by the authors. The calculation of the index is based on several innovative assumptions. First, the spatial distribution and intensity of tourist facilities in the studied mountain area is connected to the landscape background, which is the river basins. Such units integrate natural processes and are clearly visible in space.

Second, all types of tourist facilities are taken into account in the research, i.e. accommodation, food and beverage facilities, 
supporting and transport facilities. All inventoried elements are distinguished and parameterized in terms of their morphological (shape) properties. This enables to describe the physiognomic differentiation of the tourist facilities. In this case, the study include cubature elements, such as hotels, guesthouses or shelters, area elements (e.g. parking lots, downhill skiing routes) and linear elements (tourist trails, ski lifts). The tourist facility's impact on the landscape depends strongly on its spatial form. Cubature elements affect the landscape significantly, while the impact of linear elements, e.g. tourist trails, is minor. However, in this study the space in geographical scale was studied. It was considered in what degree the space was occupied by tourist facilities. This enables a quantitative assessment of the entire infrastructure of the area, as well as spatial differentiation.

An integral indicator of the degree of infrastructure density was worked out. The index is based on the ratio of the area of the tourist facilities to the total area of the unit. The method enables an objective and unified approach to assessing the strain exerted by tourist facilities on the landscape and determining the prospects for the development of these elements in the analysed area.

The novum of the work is the study of the existing tourist infrastructure in landscape (spatial) aspects in geographic field and planning scale, which is based on the density index and classification of the tourist infrastructure proposed by authors. Results presented in this paper are a part of larger study on the impact of tourist infrastructure on the physiognomy of the landscape and concentrate only on the spatial aspects.

\section{Overview of indicators used for analysis of the spatial differentiation of the development of tourism}

Diagnostic indicators are an important element of the process of tourism development, from the assessment of existing phenomenon to decisions indicating further proceedings
(Szromek, 2012). The existing measures concerning tourism development (broadly defined) can be divided into two main groups. The first (which is particularly commonplace) includes indicators measuring the phenomenon of tourism in relation to tourist traffic or the capacity of a facility or area. The second trend, related to environmental studies, measures the influence of tourism on the natural environment.

The first set of trend indicators are often used in relation to the study of tourism economics. These include Baretje-Defert (tourist function indicator, expressed in number of tourist accommodation places per 100 permanent residents) and Charvat index (saturation index of the tourist accommodation), expressed in number of granted overnight stays per 100 inhabitants of the area), as well as the accommodation density index (expressed as the number of beds offered to tourists per $1 \mathrm{~km}^{2}$ area) (Baretje \& Defert, 1972; Szromek, 2012; Hendel, 2016). The latter measures both tourist facilities and tourist traffic. The second group of indicators includes indices presenting the impact of tourism on the natural environment. They indicate changes in the natural environment caused by various types of tourist activities (Baranowska-Janota \& Kozłowski, 1984; Buckley \& Pannell, 1990; Butler, 1996; Krzymowska-Kostrowicka, 1997; PtaszyckaJackowska \& Baranowska-Janota, 1998; Sun \& Walsh, 1998; Buckly, 2004; Rixen \& Rolando, 2013; Tesler \& Clark, 2016; Bodoque et al., 2017). Limits of the impact of tourism to the natural environment can be used to establish optimal usage standards, e.g. carrying capacity (the maximum number of people that may visit a tourist destination at the same time, without causing destruction of the physical, economic, sociocultural environment and an unacceptable decrease in the quality of visitors' satisfaction, UNWTO, 1981) and, similar, natural capacity (the maximum number of people that may visit a tourist destination at the same time, which does not cause degradation in the specific character of its use, Baranowska-Janota \& Korzeniak, 1991) (Bartkowski, 1972; Marsz, 1972; O’Reilly, 1986; 
Butler, 1996; Coccossis \& Mexa, 2004; Simón, Narangajavana \& Marqués, 2004; Marsiglio, 2016; Butler, 2019). Szromek (2012) describes this group as indicators of tourist space and environment. They are the basic measures used in tourism development planning, but they do not consider existing changes in the natural environment or the landscape. Architectural methods constitute a separate group of indicators which are not directly related to tourism. This includes the urban indexes and methods concerning the physiognomic impact of buildings on the landscape, which are derived from the technical sciences. The indicators commonly used in architecture and spatial planning are i.a. index of development intensity (i.e. the ratio of the total area of all overground storeys to the parcel area, Act on spatial planning and development 2003), or Building Site Coverage (area of ground floor footprint of building divided by the parcel area, Forsyth, 2003). This indicators are also very useful for the purposes of assessing tourist facilities, but only apply to cubature elements analysed on an urban scale.

The methods of objective assessment of the impact of an individual object (not necessarily those associated with a tourist function) on a landscape are used in architectural-landscape methods. It includes visual absorption capacity (the landscape's ability to absorb physical changes without transformation in its visual character and quality, Amir \& Gidalizon, 1990) (Rygiel, 2007; Ozimek, Tarko \& Łabędź, 2010; Krajewski \& Mastalska-Cetera, 2014), visual absorption capability (a tool to assess a landscape's susceptibility to visual change caused by man's activities, Anderson et al., 1976) or visual impact assessment (a tool to estimate, in perspective view, the potential visual effect of proposed operations on the scenic landscape, Visual Impact Assessment Guidebook, 1995) (Giedych, 2016), understood as an analysis of the visibility range and aesthetic evaluation of the object itself and its impact on the environment or area assessment in terms of the possibility of accepting new facilities (often carried out for the purpose of location of wind farms, Molina-Ruiz, Martínez-Sánchez, Pérez-Sirvent, Tudela-Serrano \& García Lorenzo, 2011). The above criteria cannot be applied for development intensity analysis considered in geographical terms, in which not only cubature elements, but also area elements are taken into account.

One of the indicators illustrating the impact of tourism on the natural environment is the index of tourism development pressure on the environment (Mika, 2004). It includes a wider range of elements of tourism development compared to the methods used in the economic sciences. Mika considers the space occupied by individual elements (tourist settlements, active recreation areas and other areas with a function related to tourism) and gives them the correct value for evaluation, depending on the estimated impact on the natural environment. For the purpose of spatial analysis of tourist facilities, the above index can be the basis for further research, due to its complex approach to the issue of tourism development. However, it is not sufficient for the study of the visual aspect of landscape change under the influence of tourist facilities.

In summary, despite numerous measures being described in the literature cited above, there is a clear lack of indicators referring to landscape saturation with tourist facilities. Existing indicators related to tourism development refer to tourist traffic, accommodation, or food and beverage facilities, and they mostly focus on the number of beds, which cannot be applied to spatial research. Only the index of tourism development pressure on the environment (Mika, 2004) includes facilities other than accommodation and food and beverage (although this also does not include the entire spectrum of tourist facilities, which is largely due to a lack of statistical data).

The above-mentioned indicators also omit the issue of the magnitude of the impact on the space occupied by tourist facilities. In the landscape approach, the space occupied by various tourist facilities (not only cubature elements) is very important.

Considering the above-mentioned factors, the authors have developed a different 
indicator (see below), which in their opinion is more "objective" and useful for solving the research problem - the assessment of pressure exerted by tourist facilities on the Silesian Beskid landscape, and further optimisation of development in the area based on this assessment.

\section{Classification of tourist facilities}

It is difficult to clearly define the term of 'tourist infrastructure' (Mandic, Mrnjavac \& Kordić, 2018). It includes physical elements - facilities necessary to receive tourists (Jovanović \& Ivić, 2016) but often includes also services necessary to develop tourist reception area (Gunn \& Var, 2002; Kowalczyk \& Derek, 2010). In the current paper, the term 'tourist facilities' will be used to refer to the physical infrastructure (settlements, roads, parking spaces, trails and tourist and recreation routes) used for tourist activities, which shape and change the landscape.

The classification of tourist infrastructure is not unified. In Polish-language papers, there are numerous criteria of classification. including function, time of use, accessibility to users, spatial form and geographical distribution (Kowalczyk \& Derek, 2010). According to the division most commonly accepted in tourism, based on the function criterion (Rogalewski, 1974; Warszyńska \& Jackowski, 1978), accommodation, food and beverage, transport and supporting facilities and services can be distinguished. Accommodation facilities include, i.a., hotels, hostels, youth hostels, motels, camp sites, resorts, home stays, agro-tourism accommodation, holiday and training resorts, clusters of houses or bungalows, and health resorts (Płocka, 2005; Statistical Yearbooks of the Central Statistical Office, 2018). Food and beverage facilities include, i.a., restaurants, bars, cafés, teahouses, confectioners, wine bars, and pubs (Płocka, 2005). Transport facilities concern i.a. parking lots, tourist trails, ski lifts and also technical infrastructure as roads, airports and railways system (Kowalczyk \& Derek, 2010). Supporting facilities include tourist information, services facilities necessary for tourist (as medical services, souvenir shops. post agency), cultural-entertainment facilities (as museums, cinemas) and sports and recreation facilities as pools, sports halls (Płocka, 2005). Pawlikowska-Piechotka (2008) classifies tourist and recreational facilities (such as pools, ski lifts, sports fields, tennis courts) and others (semi-tourist) (such as museums, theatres, cinemas) as supporting facilities. A different classification is presented in the WTO classification (International Recommendations for Tourism Statistics 2008). In this document, tourist facilities are presented in relation to characteristic tourist activities or industries. The main groups of tourism industries are distinguished: accommodation, food and beverage provision, passenger transportation, travel agencies and other reservation services activities, cultural activities, sport and recreational activities, retail trade of country-specific characteristic foods for tourists and other country-specific characteristic activities.

In most studies evaluating existing tourist infrastructure, a classification using the function criterion is used (Płocka, 2009; Bogucka, 2010), and the evaluation refers most of all to accommodation and food and beverage facilities. Narrowing the approach to these two functional types is reflected in tourism function indicators. The classification of tourist infrastructure plays a key role in assessing existing elements, and deciding whether or not to include an element in research. Focusing on accommodation and food and beverage elements leads to a lack of indicators in planning further development for recreational and sports facilities, which are appearing more and more often in the tourist landscape (e.g. rope parks, toboggan runs). As a consequence, we often find littering and the commercialization of space resulting from the accumulation of these elements.

Table 1 presents a proposition for the classification of tourist facilities, combining spatial and functional aspects. The presented classification has been used in the presented study on the density of tourist facilities. 
Table 1. Classification of tourist facilities

\begin{tabular}{|c|c|c|c|c|}
\hline \multicolumn{2}{|c|}{ Tourist facilities } & Cubature elements & Area elements & Linear elements \\
\hline \multicolumn{2}{|c|}{$\begin{array}{l}\text { Accommodation facilities } \\
\text { Food and beverage facilities }\end{array}$} & $\begin{array}{l}\text { Hotels, hostels, apart- } \\
\text { ments, bed\&breakfast, } \\
\text { youth hostels, motels, } \\
\text { resorts, homestays, agri- } \\
\text { tourism accommodation, } \\
\text { holiday\&training resorts, } \\
\text { health resorts, } \\
\text { Restaurants, bars, cafés, } \\
\text { teahouses, confectioner- } \\
\text { ies, wine bars, pubs, } \\
\text { fast food, cocktail bars } \\
\text { (if located in separated } \\
\text { buildings), }\end{array}$ & $\begin{array}{l}\text { Clusters of houses } \\
\text { or bungalows, camping, } \\
\text { campgrounds, }\end{array}$ & - \\
\hline 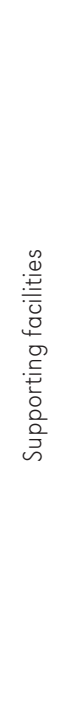 & $\begin{array}{l}\text { Trade and service } \\
\text { Culture and recreation } \\
\text { Sports and recreation } \\
\text { Health and spa }\end{array}$ & $\begin{array}{l}\text { Tourist information cen- } \\
\text { tres (if located in sepa- } \\
\text { rated buildings), } \\
\text { Souvenir shops (if located } \\
\text { in separated buildings), } \\
\text { Amphitheatre, theatre, } \\
\text { cinemas, museums, exhi- } \\
\text { bition rooms, events halls, } \\
\text { Sports halls, swimming } \\
\text { pools, ski jumps, horse } \\
\text { riding halls, lookout } \\
\text { towers, } \\
\text { Sanatoriums, spas and } \\
\text { wellness centres, mineral } \\
\text { water pump room, gradu- } \\
\text { ation towers, }\end{array}$ & $\begin{array}{l}\text { Outdoor events areas, } \\
\text { Tennis courts, sports } \\
\text { fields, parks, downhill } \\
\text { runs, summer toboggan } \\
\text { runs, off-road areas, } \\
\text { training areas, paintball } \\
\text { fields, mini-zoo, horse } \\
\text { farms, golf courses, } \\
\text { amusement parks } \\
\text { - }\end{array}$ & - \\
\hline 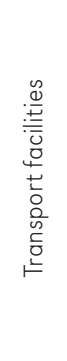 & $\begin{array}{l}\text { Ski lifts and tourist } \\
\text { railways }\end{array}$ & $\begin{array}{l}\text { Lookout towers, shelters, } \\
\text { resting places, marinas, } \\
\text { Ski lift station, rescue } \\
\text { centres, }\end{array}$ & Car parks, airports & $\begin{array}{l}\text { Hiking, biking, skiing, } \\
\text { water, horse trails, educa- } \\
\text { tional paths, } \\
\text { Aerial tramways, } \\
\text { chairlifts, } \\
\text { gondola lifts, } \\
\text { hybrid lifts, } \\
\text { surface lifts, } \\
\text { Roads, railways, prom- } \\
\text { enades, boulevards }\end{array}$ \\
\hline
\end{tabular}

Source: Own compilation based on Kowalczyk, Derek, 2010; Płocka, 2005; Statistical Yearbook, 2018.

The authors of this study propose taking into account the spatial division of elements into cubature, area and linear elements (see chapter 5. Methods).

\section{Geography of the study area}

The study area is located in Poland, in the Western Carpathian mountains. It covers 
the geographical macroregion of the Silesian Beskids (Kondracki, 2002) and also, in accordance with the latest division into mesoregions (Balon, Jodłowski \& Krąż, 2018; Solon et al., 2018), comprises part of the Koniaków Intermontane mesoregion (Fig. 1). The location of the area, in the immediate vicinity of large towns (Bielsko-Biała and Żywiec) and a few dozen kilometres from the Katowice conurbation, is important for the development of tourism. The area has particular landscape values, determined by the diversity of the relief (rolling hills, whose which height reaches 1000-1500 m above sea level, with denivelations of 300-600 m), significant areas of forests, rivers and springs, and also the specific culture of the region (Mika, 97). The presence of spa resources, which was crucial to the development of tourism, is also significant (Gonda-Soroczyńska, 2013).

The conditions mentioned above have impacted land use and led to tourism being of particular importance in the development of the region. The natural landscape of the Beskids has been strongly transformed, to a large extent under the influence of activities related to tourism. The area was and still is under strong pressure from tourism (Mika, $2001,2004)$. It is also characterized by a diversity of forms of tourism, and therefore there

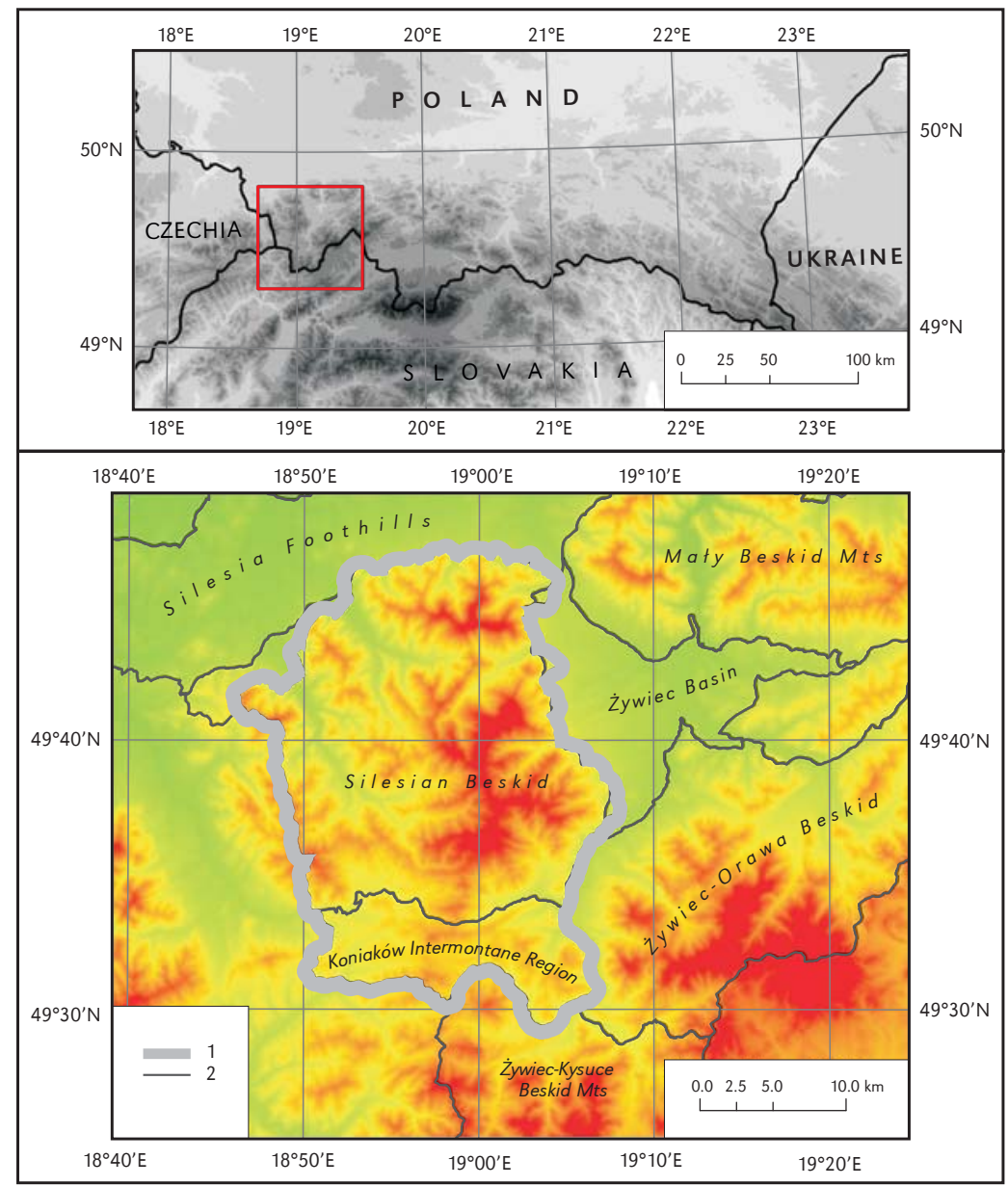

Figure 1. Location of the study area; 1 - study area boundaries, 2 - mesoregions boundaries 
are various tourist facilities, which are functionally and spatially different. The large hotels and resorts are located mostly in Ustroń and Wisła, while small accommodations, like guest rooms and "second homes" or recreation houses, are situated in Szczyrk, Brenna and so-called Triple Village (Koniaków, Istebna, Jaworzynka). The tourist activities are also diversified. In Triple Village more important is cultural tourism (Faracik, Kurek, Mika, Pawlusiński, 2009). In Ustroń, Wisła and Szczyrk the mass tourism is present, which is proved by high Defert index for this municipalities (Hendel, 2016). The special landscape and natural values combined with the pursuit of tourism development have led to numerous conflicts between landscape preservation and tourism (Mika, 1997; Mika, Krzesiwo \& Krzesiwo, 2007; Myga-Piątek \& Jankowski, 2009).

Numerous areas of the Silesian Beskids are under excessive tourist pressure and there has been a significant reduction in landscape values due to the accumulation of tourist facilities (Mika, 2004). The uncontrolled accumulation of tourist attractions has caused a decrease in landscape values which can be observed, for example, on the slopes of Równica. Although the mountain hostel was built in the 1920s, and road access was provided in the 1930s, tourism developed particularly rapidly at the turn of the 20th and 21st centuries (Barański, 2007). In last 20 years, not only have numerous accommodation and catering facilities been built on the slopes of Równica, but so have a rope and paintball park, a zoo, a toboggan run and car parks serving the above attractions (Petryszyn \& Zuzańska-Żý́ko, 2009).

The spatial conflicts mentioned above and the lack of evaluation of the impact of tourism on the physiognomy of the landscape were the basis for choosing the Silesian Beskids as the study area.

\section{Methods}

The following research algorithm was used in the presented studies: after determining the boundaries of the study, based on Kondracki's mesoregions (2002), delimitation of the primary (spatial) units based on the basin model was carried out. Next, an inventory of tourist facilities according to the developed classification was made and related to individual spatial units. The final step was to determine the index and calculate the density of tourist facilities for the studied area.

\section{Delimitation of primary units}

As mentioned above, in this study the primary spatial unit (used in calculations) is a river basin of the appropriate category (microbasin). The use of microbasins as a primary unit in landscape research is not a typical approach (Żemła-Siesicka, 2017). In research on tourist facilities, administrative divisions are most often used as primary units. This is undoubtedly a convenient approach, because decisions and statistics regarding tourism are provided in relation to administrative boundaries. However, the presented goal, related to the analysis of the impact of existing facilities on space in the landscape, requires a different, more "visual" approach. This is due to the fact that, in mountain areas, catchments (understood here as individual valleys determined on the basis of water divides), create clear, visible and cohesive units. Conversely, artificially-set administrative boundaries are "invisible" in the field (although some boundaries between communes coincide with clearly visible topographic elements).

Basins are usually used as spatial units in hydrographic studies (e.g. Lipski, Kostuch \& Ryczek, 2005; Małek \& Gawęda, 2005), landscape dynamics and function studies (e.g. on geodiversity: Najwer \& Zwoliński, 2014), and rarely in other studies (np. Zolotov \& Chernykh, 2015). In the case of spatial studies in mountain areas, basins form functional units integrating natural processes (Kistowski, 2001) and processes related to land cover (Bertolo, 2000).

Using the basin criterion, it was possible to obtain spatial units based on water divides 
of various categories, ranging from the European watershed to category III water divides (water divides marked on a hydrographic map (geoportal.gov.pl, 1:50,000 scale) were used). As a result, 68 spatial units were obtained, delimited in the catchments of smaller rivers in the northern part of the Beskids (units 513.451.1-513.451.11), in the catchment of the Brennica (units 513.452.1-513.452.8), Żylica (units 513.453.1-513.453.5) and Vistula (units 513.454.1-513.454.16), in the catchment of Soła on eastern slopes of Barania Góra (units 513.455.1-513.455.11) and Olza (units 513.456.1-513.456.10), and in the area between Soła and its tributaries - Roztoka and Janaszka (units 513.457.1-513.457.7).

\section{Inventory of tourist facilities}

The tourist facilities of the Silesian Beskids were divided into area elements (e.g. camp sites), cubature elements (e.g. hotels) and linear elements (e.g. tourist trails). This kind of division based on spatial form is presented and defined by Kowalczyk and Derek (2010). Based on their adopted and modified definitions, the authors of this article developed the following terms: cubature elements are an association of tourist facilities gathered in one building, which have tourism as the sole or predominant function.

Linear elements, which were considered by Kowalczyk and Derek (2010) to be tourist trails, have been extended in this research to include ski lifts (classified by Kowalczyk and Derek as area facilities) due to their linear character and particular impact on the landscape. So linear elements include linear technical elements such as ski lifts and elements without technical equipment as tourist paths and trails. In the research only separated trails and paths were taken into account, i.e. if several trails have the same route, they are considered as one element, and if a trail or path overlaps with a circular road it is not considerate. Those assumptions results from the fact that the space (area) is the main criterion taken into consider, so it can't be duplicate.
Area elements are areas that perform tourist or recreational functions without buildings, as well as complexes of facilities with an area of ground floor footprint less than $50 \mathrm{~m}^{2}$ (e.g. clusters of houses or bungalows, camp sites). If there is a building associated with an area element (i.e. ticket and ski rental office at the foot of downhill slope), these buildings are considerate separately as cubature elements.

\section{Calculation of the density of tourist facilities}

To calculate the density of tourist facilities, an index based on existing similar tourism indices, particularly on the density of accommodation index, was proposed. The density of tourist facilities index is a quantity indicator specifying the intensity of the area, including all facilities. The index is calculated according to the formula:

$$
G_{i}=P_{i} / P_{j} \times 100
$$

where:

$G_{i}$ - density of tourist facilities

$P_{i}$ - area of all facilities $\left(\mathrm{m}^{2}\right)$ within a given spatial unit

$P_{\mathrm{j}}$ - area of a spatial unit $\left(\mathrm{m}^{2}\right)$

Area of all facilities is calculated on the base of summary of area of the cubature elements, area of the area elements and area of the linear elements. The area of cubature and area elements was provided from GIS, the linear elements area was calculated on the base of the length of the elements multiplied by the assumed average width of $3 \mathrm{~m}$ in the case of trails and paths, of $5 \mathrm{~m}$ in the case of ground ski lift and of $6 \mathrm{~m}$ in the case of chair and gondola lift.

\section{Results \\ Occurrence of tourist facilities in the studied area}

Inventory of tourist facilities in the studied area shows that the cubature elements are concentrated along rivers, especially the 
main rivers of Silesian Beskid. The most numerous are small cubature elements, i.e. hostels, small hotels, restaurants, bars and mountain shelters. The least numerous are large cubature elements, i.e. those located in Szczyrk and Wisła (Gołębiewski hotel in Wisła, Jawornik hotel in Wisła-Jawornik, Orle Gniazdo hotel in Szczyrk-Biła). Many hotels are located in holiday districts such as Ustroń-Zawodzie and Ustroń-Jaszowiec, most of which were built in the period of People's Republic of Poland (PRL - Polska Republika Ludowa). Some of these have been modernized (e.g. Gwarek in Ustronie-Jaszowiec), and some parts have been completely rebuilt. Some of the facilities have been closed, such as Magnus Resort in Bystra. Guest houses, homestays and agro-tourism accommodation (usually this is true in name only, and these are de facto guest rooms located in separate buildings especially designed for tourists) occur frequently almost throughout the entire area. A particularly high concentration can be observed along the Vistula, Brennica and Żylica valleys. Numerous elements are dispersed in Istebna. In the last decade or so, the number of food and beverage facilities has increased significantly, especially restaurants - inns designed in the highland style, most often on the main roads but also in the higher mountain areas, e.g. in Równica. The spatial distribution is presented on figure 2 .

Area elements are represented in Silesian Beskids by transportation elements (parking) and rarely by accommodation facilities (campsites, clusters of bungalows). Car parks with different areas are very numerous throughout the study area, constituting one of the basic elements of technical infrastructure. Most of them are located near ski lifts. Area elements inventoried in Silesian Beskid also include facilities for recreation and sports: tennis courts, sports fields, outdoor swimming-pools and parks and also more typical tourist elements: off-road trails, rope parks, paintball fields and a mini-zoo. Other important element of tourist facilities include downhill runs, ski slopes and one cross-country skiing area (concentrated in Kubalonka). A spatial distribution shows that these elements occur the most often in central and west areas of the Silesian Beskid, in Wisła, Szczyrk and Brenna.

Linear elements occur throughout almost the entire area of the Silesian Beskids. This includes transportation elements: hiking, biking, skiing routes, educational paths, ski lifts, cable cars, MTB routes, promenades. Hiking routs are the most common tourist elements, forming a dense network covering almost the whole area of the study, except for the south-eastern part. Educational paths are also common but, as they are usually part of walking routes, they were not separated in the research, with the exception of the nature path "In the Zimnik Valley" at the foot of Skrzyczne (the path doesn't lead together with other tourist trails). The specific layout of the routes depends, to a certain extent, on tourist values, first of all on the relief, but also it results from the methodological assumptions of the studies, which did not take into account the tourist routes running along roads. This is why the visible system refers very clearly to the water divisions - most of the routes run along mountain ridges.

Ski lifts in Silesian Beskid form a specific system. Usually, they form isolated elements; only on Czantoria and in Szczyrk they show a network character. In the Silesian Beskids, ski lifts, and the increasingly common chairlifts occur frequently. The main centre for ski infrastructure is Szczyrk, which has recently undergone significant changes. Numerous ski lifts are also located in Wisła, Ustoń, Brenna and Zwardoń. In recent years, the ski centre in Istebna with lifts on the slopes of Złoty Groń has also been developed.

Quantitative analysis shows the dominance of cubature elements (514 cubature elements, 187 area elements and 432,42 km of linear elements). Most of elements is located in the valleys of Vistula, Żylica and Brennica. Some elements occur in area of Istebna-Koniaków-Jaworzynka. In south-east of Silesian Beskid there are very few of cubature and area elements and some linear elements. 


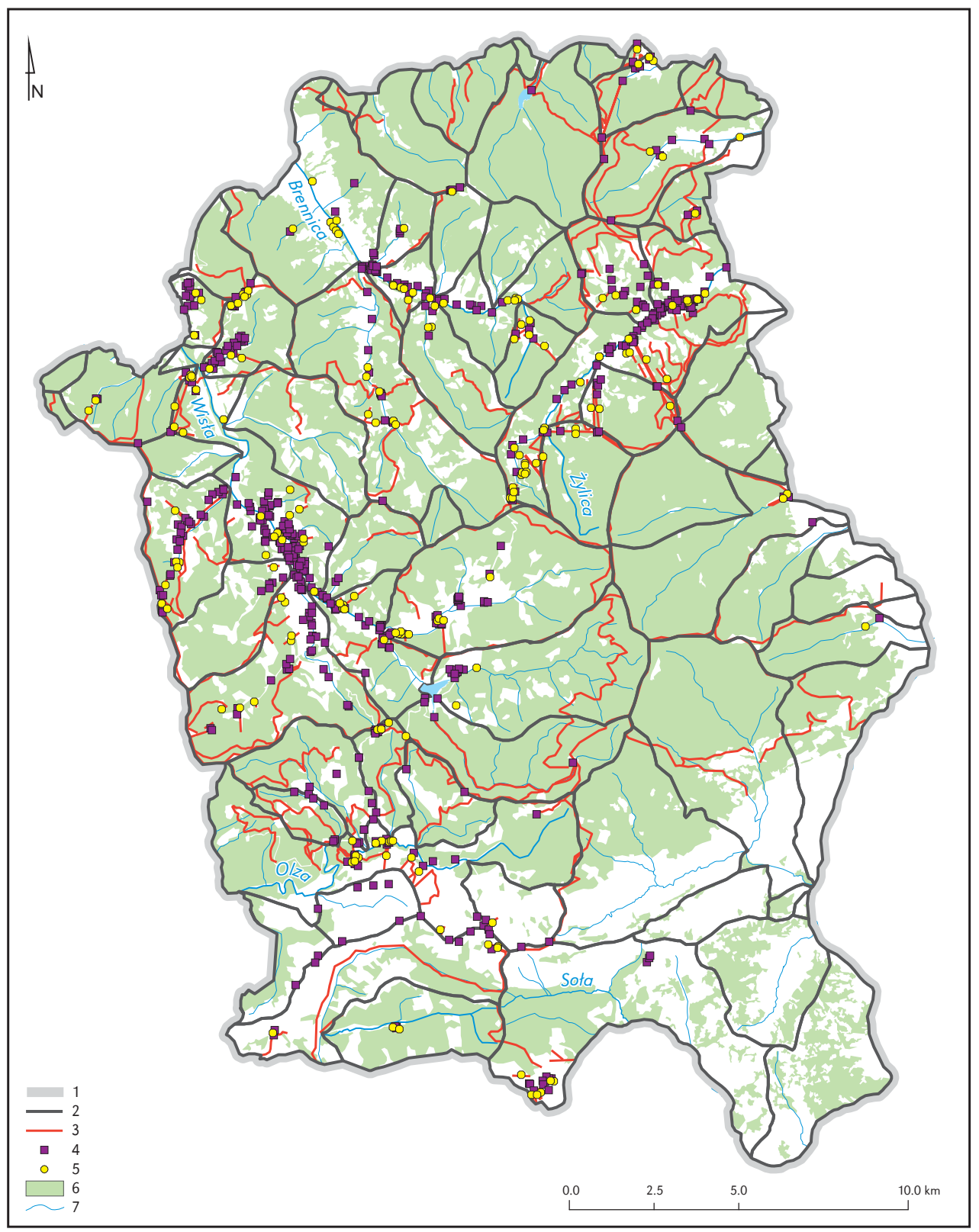

Figure 2. Spatial distribution of facilities in the Silesian Beskid mountain region. 1 - study area boundaries, 2 - spatial unit boundaries, 3 - linear elements, 4 - cubature elements, 5 - area elements, 6 - forests, 7 - rivers 


\section{Density of tourist facilities in the studied area}

On the basis of the inventory, density index calculations for each of the spatial units (primary units) were made. The values of indicators remain closely correlated to the area occupied by individual elements. The units with the highest value of the index are: 513.453 .4 (North-eastern slopes of Skrzyczne, 18.68) and 513.451.7 (Dębowiec, 11.90). Those high values are the result of the occurrence of large areas of downhill runs and, additionally, several point elements. High values also appear for the units 513.454.2 (Ustron'-Zawodzie, 8.46), 513.452.7 (Brenna-Węgierski, 6.32), 513.456.2 (Istebna-Kubalonka, 5.95) and 513.453.2 (Szczyrk in Żylica valley, 5.75). The lowest values characterise the units located in the eastern part of studied area (microregions 513.455 and 513.457 ). There are very few units with an index of zero: 513.451.4, 513.452.4, 513.452.8, 513.454.4, 513.455.2, $513.455 .3,513.455 .6,513.457 .2,513.457 .3$, 513.457.4, 513.457.6, 513.457.7. The values of the received index are presented in Table 2.

The most intensely developed areas in terms of tourist facilities are areas in the

Table 2. The values of the tourist facility density index for spatial units

\begin{tabular}{|l|c|l|c|l|c|}
\hline Spatial unit & $\begin{array}{c}\text { Values of the } \\
\text { tourist facilities } \\
\text { density index }\end{array}$ & Spatial unit & $\begin{array}{c}\text { Values of the } \\
\text { tourist facilities } \\
\text { density index }\end{array}$ & Spatial unit & $\begin{array}{c}\text { Values of the } \\
\text { tourist facilities } \\
\text { density index }\end{array}$ \\
\hline 513.453 .4 & 18.68 & 513.452 .6 & 0.58 & 513.455 .11 & 0.16 \\
513.451 .7 & 11.90 & 513.454 .11 & 0.53 & 513.455 .10 & 0.14 \\
513.454 .2 & 8.46 & 513.454 .5 & 0.51 & 513.454 .9 & 0.12 \\
513.452 .7 & 6.32 & 513.457 .5 & 0.47 & 513.455 .1 & 0.11 \\
513.456 .2 & 5.95 & 513.453 .3 & 0.43 & 513.455 .8 & 0.10 \\
513.453 .2 & 5.75 & 513.454 .16 & 0.41 & 513.457 .1 & 0.07 \\
513.454 .3 & 3.30 & 513.456 .3 & 0.36 & 513.452 .3 & 0.07 \\
513.454 .8 & 3.13 & 513.454 .14 & 0.36 & 513.455 .7 & 0.04 \\
513.452 .2 & 2.67 & 513.456 .7 & 0.35 & 513.456 .6 & 0.03 \\
513.453 .1 & 2.52 & 513.454 .6 & 0.33 & 513.456 .8 & 0.01 \\
513.454 .10 & 2.36 & 513.455 .4 & 0.29 & 513.451 .4 & 0.00 \\
513.451 .8 & 1.19 & 513.451 .3 & 0.28 & 513.452 .4 & 0.00 \\
513.456 .5 & 1.12 & 513.454 .12 & 0.28 & 513.452 .8 & 0.00 \\
513.452 .5 & 1.11 & 513.456 .1 & 0.25 & 513.454 .4 & 0.00 \\
513.451 .10 & 1.09 & 513.453 .5 & 0.24 & 513.455 .2 & 0.00 \\
513.452 .1 & 0.98 & 513.451 .2 & 0.22 & 513.455 .3 & 0.00 \\
513.454 .13 & 0.93 & 513.456 .10 & 0.22 & 513.455 .6 & 0.00 \\
513.451 .11 & 0.83 & 513.454 .7 & 0.22 & 513.457 .2 & 0.00 \\
513.456 .4 & 0.71 & 513.451 .5 & 0.20 & 513.457 .3 & 0.00 \\
513.451 .9 & 0.68 & 513.455 .9 & 0.19 & 513.457 .4 & 0.00 \\
513.451 .1 & 0.67 & 513.455 .5 & 0.18 & 513.457 .6 & 0.00 \\
513.454 .1 & 0.59 & 513.454 .15 & 0.18 & 513.457 .7 & 0.00 \\
513.456 .9 & 0.58 & 513.451 .6 & 0.17 & & - \\
\hline
\end{tabular}


western and central part of the Silesian Beskids (Fig. 3). A particularly intense density of tourist facilities has occurred in the Żylica basin (Szczyrk), and a slightly lower density can be observed in the basin of Brennica, Vistula and Olza. The lowest density occurs on the eastern slopes of Barania Góra and in the south-eastern part of the Silesian Beskids. located in the central and western part of the Silesian Beskids, and the least developed are in the south-eastern part. The areas in the central and western parts of the Silesian Beskids are the best developed, while the south-eastern part is the least developed. Similar results concerning tourism in Silesian Beskid were obtained by Mika (2004) in the study of the

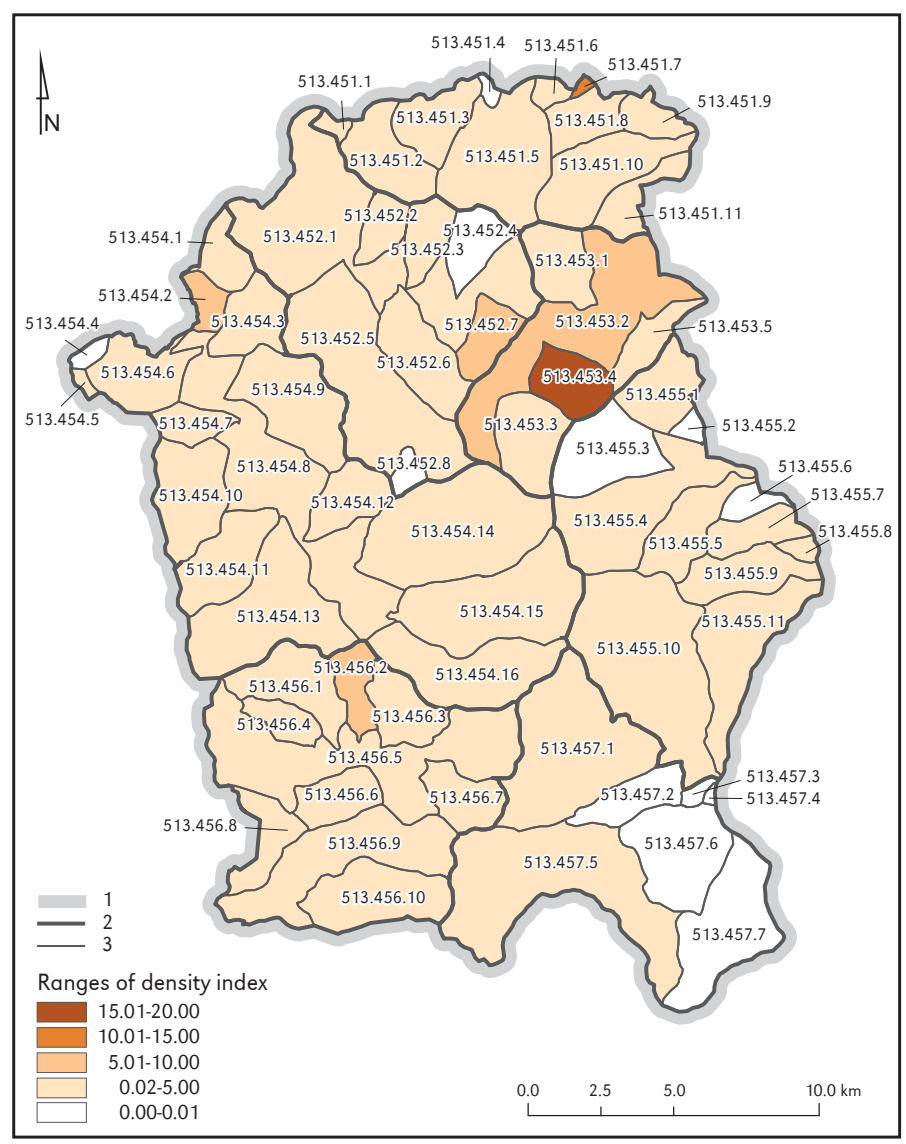

Figure 3. Density of the tourist facilities in the Silesian Beskid mountain region. 1 - study area boundaries, 2 - main catchments boundaries, 3 - spatial unit boundaries

\section{Discussion}

The results show the spatial distribution and spatial diversity of tourist facilities in the Silesian Beskids area. The density index shows that the most developed areas in terms of the occurrence of tourist facilities are those impact of tourism on the natural environment and by Hendel (2016) in the evaluation of tourism development assessed by Defert and Charvat index. Both research were conducted for administrative areas (municipalities). Although Defert and Charvat index are measure of tourist traffic, their relation to the tourist infrastructure and thus to the impact 
on the landscape is clear. The areas of Szczyrk, Wisła, Ustroń, Brenna and Bystra are the most transformed in the assessment of both the environmental impact and the density index. In Hendels' study the highest values are reported for Ustroń, followed by Szczyrk and Wisła, while Brenna have values even several times lower. The case of Brenna shows differences in results depending on the kind of infrastructure considered in study. While the accommodation facilities (which are taken into account in Defert and Charvat index) are not so much developed, the other kind of tourist infrastructure (considered in Mika indicator and in density index) are numerous. It should be also noted that the river basin units adopted in the article allow a much more detailed presentation of the impact of tourism than larger administrative units.

Based on the values of the index obtained in this particular area, it is possible to indicate the opportunities and limitations of their further development (in a spatial sense). Therefore, units were assigned to five groups, depending on the value of index: areas indicated as recommended for further development (minimal value of the index, interval of index 0-0.5), areas where further development is possible (interval of index $\geq 0.5-1$ ), areas where further development should be limited (interval of index $\geq 1-5$ ), areas where further development should be strongly limited (inter$\mathrm{val}$ of index $\geq 5-10$ ) and areas where further development is forbidden (interval of index $\geq 10-20$ ).
However, it should be remembered that the final evaluation of the area depends also on other conditions: natural, such as forest cover or surface waters, but also economic or social situation. In this particular spatial studies it was considered that forest cover has the greatest impact on the distribution of elements, because it is a form of land protection that prevents any permanent development. The forestation in Silesian Beskid is very differentiated. The forest cover mostly the north part of study area and in the south the percentage of forest cover is very low. The opportunities for tourist investments are strongly limited in units covered mostly or entirely by forests. In these cases, only linear elements (tourist trails) should be developed. On the other hand, if the area is almost unforested, there is a space for tourist investments. Therefore, the division was additionally supplemented with information on the extent of forest cover. Forest cover was divided into intervals $(<40 \%, \geq 40-60 \%$, $\geq 60-80 \%$ and $\geq 80 \%$ ) and assigned to the groups mentioned above. So the first step was the division of density index. Than intervals of forest cover were the second criterion of providing the groups of indicated development. The results of the division are shown in table 3 . The results of integral evaluation are shown in the table 4.

As seen below (Fig. 4), the areas possible to invest in or recommended for further development are located in south-eastern parts of Silesian Beskid mountain region and cover

Table 3. Criteria of division of groups of opportunities of tourist facilities development

\begin{tabular}{|l|c|c|}
\hline \multicolumn{1}{|c|}{ Development } & Criterion of density index & Additional criterion of forest cover \\
\hline Forbidden & $\geq 10-20$ & irrelevant \\
Strongly limited & $\geq 5-10$ & irrelevant \\
& $<5$ & $\geq 80 \%$ \\
Limited & $\geq 1-5$ & irrelevant \\
& $<1$ & $\geq 60-80 \%$ \\
Possible & density index & irrelevant \\
& $\geq 0.5-1$ & $\geq 40-60 \%$ \\
Recommended & $<0.5$ & $<40 \%$ \\
& density index & \\
\hline
\end{tabular}


Table 4. Types of units indicating opportunities of further development of tourist facilities within the Silesian Beskid mountain region

\begin{tabular}{|c|c|c|c|c|c|c|c|}
\hline $\begin{array}{l}\text { Develop- } \\
\text { ment }\end{array}$ & Criterion & $\begin{array}{l}\text { Spatial } \\
\text { unit }\end{array}$ & $\begin{array}{c}\text { Values of the } \\
\text { tourist } \\
\text { facilities } \\
\text { density index }\end{array}$ & $\begin{array}{c}\text { Forest cover } \\
{[\%]}\end{array}$ & $\begin{array}{l}\text { Spatial } \\
\text { unit }\end{array}$ & $\begin{array}{l}\text { Values of the } \\
\text { tourist } \\
\text { facilities } \\
\text { density index }\end{array}$ & $\begin{array}{c}\text { Forest cover } \\
{[\%]}\end{array}$ \\
\hline Forbidden & $\begin{array}{l}\text { density index } \\
<10 ; 20)\end{array}$ & 513.453 .4 & 18.68 & 79 & 513.451 .7 & 11.9 & 63 \\
\hline \multirow{13}{*}{$\begin{array}{l}\text { Strongly } \\
\text { limited }\end{array}$} & \multirow{13}{*}{$\begin{array}{l}\text { density index } \\
<5 ; 10) \\
\text { forest cover } \\
<80 \% ; 100 \%)\end{array}$} & 513.454 .2 & 8.46 & 55 & 513.456 .2 & 5.95 & 81 \\
\hline & & 513.452 .7 & 6.32 & 86 & 513.453 .2 & 5.75 & 50 \\
\hline & & 513.451 .8 & 1.19 & 88 & 513.453 .5 & 0.24 & 84 \\
\hline & & 513.451 .10 & 1.09 & 80 & 513.451 .2 & 0.22 & 93 \\
\hline & & 513.451 .9 & 0.68 & 97 & 513.455 .5 & 0.18 & 82 \\
\hline & & 513.451 .1 & 0.67 & 100 & 513.451 .6 & 0.17 & 99 \\
\hline & & 513.454 .1 & 0.59 & 89 & 513.455 .1 & 0.11 & 85 \\
\hline & & 513.452 .6 & 0.58 & 82 & 513.452 .8 & 0.00 & 100 \\
\hline & & 513.454 .5 & 0.51 & 100 & 513.455 .3 & 0.00 & 99 \\
\hline & & 513.453 .3 & 0.43 & 95 & 513.454 .4 & 0.00 & 98 \\
\hline & & 513.454 .16 & 0.41 & 82 & 513.455 .2 & 0.00 & 92 \\
\hline & & 513.454 .6 & 0.33 & 90 & 513.451 .4 & 0.00 & 91 \\
\hline & & 513.451 .3 & 0.28 & 99 & 513.452 .4 & 0.00 & 83 \\
\hline \multirow[t]{12}{*}{ Limited } & \multirow{12}{*}{$\begin{array}{l}\text { density index } \\
<1 ; 5) \\
\text { forest cover } \\
<60 \% ; 80 \% \text { ) }\end{array}$} & 513.454 .3 & 3.30 & 71 & 513.454 .10 & 2.36 & 66 \\
\hline & & 513.454 .8 & 3.13 & 45 & 513.456 .5 & 1.12 & 43 \\
\hline & & 513.452 .2 & 2.67 & 66 & 513.452 .5 & 1.11 & 46 \\
\hline & & 513.453 .1 & 2.52 & 65 & - & - & - \\
\hline & & 513.454 .13 & 0.93 & 62 & 513.456 .1 & 0.25 & 77 \\
\hline & & 513.451 .11 & 0.83 & 69 & 513.456 .10 & 0.22 & 76 \\
\hline & & 513.456 .4 & 0.71 & 77 & 513.454 .7 & 0.22 & 74 \\
\hline & & 513.454 .11 & 0.53 & 71 & 513.451 .5 & 0.20 & 71 \\
\hline & & 513.456 .3 & 0.36 & 78 & 513.455 .9 & 0.19 & 77 \\
\hline & & 513.454 .14 & 0.36 & 69 & 513.454 .15 & 0.18 & 61 \\
\hline & & 513.455 .4 & 0.29 & 71 & 513.454 .9 & 0.12 & 73 \\
\hline & & 513.454 .12 & 0.28 & 79 & 513.452 .3 & 0.07 & 79 \\
\hline \multirow[t]{5}{*}{ Possible } & \multirow{5}{*}{$\begin{array}{l}\text { density index } \\
<0.5 ; 1) \\
\text { forest cover } \\
<40 \% ; 60 \% \text { ) }\end{array}$} & 513.452 .1 & 0.98 & 35 & 513.456 .9 & 0.58 & 32 \\
\hline & & 513.455 .11 & 0.16 & 51 & 513.456 .8 & 0.01 & 45 \\
\hline & & 513.455 .10 & 0.14 & 41 & 513.457 .3 & 0.00 & 48 \\
\hline & & 513.457 .1 & 0.07 & 52 & 513.457 .7 & 0.00 & 44 \\
\hline & & 513.455 .7 & 0.04 & 50 & 513.457 .6 & 0.00 & 43 \\
\hline \multirow{4}{*}{$\begin{array}{l}\text { Recom- } \\
\text { mended }\end{array}$} & \multirow{4}{*}{$\begin{array}{l}\text { density index } \\
<0 ; 0.5) \\
\text { forest cover } \\
<0 \% ; 40 \%)\end{array}$} & 513.457 .5 & 0.47 & 38 & 513.455 .6 & 0.00 & 33 \\
\hline & & 513.456 .7 & 0.35 & 11 & 513.457 .4 & 0.00 & 13 \\
\hline & & 513.455 .8 & 0.10 & 2 & 513.457 .2 & 0.00 & 10 \\
\hline & & 513.456 .6 & 0.03 & 7 & - & - & - \\
\hline
\end{tabular}




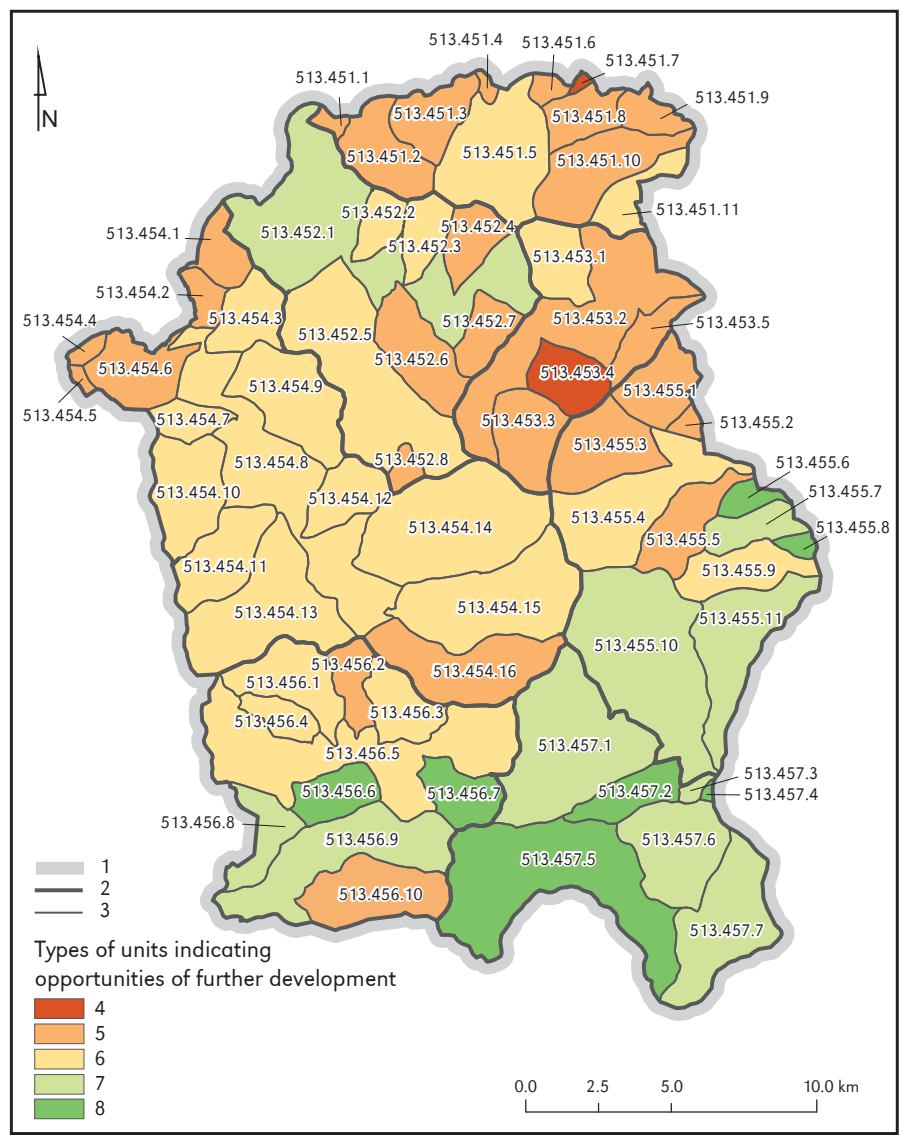

Figure 4. Types of units indicating opportunities of further development of tourist facilities in the Silesian Beskid mountain range. 1 - study area boundaries, 2 - main catchments boundaries, 3 - spatial unit boundaries, 4 - forbidden, 5 - strongly limited, 6 - limited, 7 - possible, 8 - recommended

a large part of it. The largest part of the area, located in the northern and western regions, are covered by units where further development is limited and strongly limited. Further investments in these areas should therefore be carefully considered, because the location of new objects could lead to a significant reduction in landscape values.

\section{Conclusion}

Based on above results, the following conclusion can be provided:

- the spatial distribution of tourist facilities in Silesian Beskid is differentiated, the cubature elements are concentrated along rivers, especially the main rivers of Silesian Beskid, area elements occur the most often in central and west areas of the Silesian Beskid, in Wisła, Szczyrk and Brenna, linear elements are present in almost the entire area of the Silesian Beskids,

- the density index shows that the most intensely developed areas in terms of tourist facilities, which can be considered as overloaded, are areas in the western and central part of the Silesian Beskids,

- differences in the result of the comparison with the Charvat and Defert indexes indicate that all types of tourist infrastructure, including accommodation, food and beverage facilities, supporting and transport 
infrastructure should be taken into account. Those differences prove also the need to introduce an indicator for tourism spatial studies.

The conducted studies on the density of tourist facilities in the area of Silesian Beskids have both scientific and application implications. First, the proposed method allows to describe and understand the spatial implications of the tourism. Both proposed classification and the density index contribute a new possibilities to measure the influence of tourism on the landscape. The second contribution of the article is an application one. As was mentioned in the Introduction, an indication of the intensity of tourist facilities development is very important for the planning of further investments. The obtained results enable the evaluation of the pressure exerted by tourist facilities on the landscape of the Silesian Beskids, and the determination of further development optimisation in the studied area. The presented density index can be used for studies of tourist facilities as a basis for indicating opportunities for further development.

However, it is worth to notice, that to indicate the further development of tourist facilities, it is important to examine diverse approaches, not only the spatial dimension. Research in other areas is equally important, including environmental protection (impact of new investments on soils, water, air, etc.), economics (study of the profitability of new facilities) or tourism (research on tourist preferences). The presented research only highlights the significant impact of tourism infrastructure on the landscape space. The spatial-physiognomic aspect of the tourist region largely determines if the area is attractive to tourists or not. Taking care of landscape quality is therefore in the interest not only of tourists, but also of the local population who benefit economically from tourism.

The presented method of analysis and indications regarding tourist facilities was tested for a specific area, so it can be used primarily in mountains similar to Silesian Beskid, (as Beskid Żywiecki) due to the adopted basin spatial units which are useful for areas where the valleys are clearly visible. The method should be also tested in other areas to verify its suitability. If administrative units were substituted as a primary units, the density index could also be applied in lowland areas. With minor methodological corrections (adopting other primary units) it would also be possible to assess landscape changes on a more detailed scale and in a smaller area (e.g. for municipalities).

Editors' note:

Unless otherwise stated, the sources of tables and figures are the authors', on the basis of their own research.

\section{References}

Agarwal, S. (1998). Reply - what new with the resort cycle? Tourism Management, 19(2), 181-182.

Amir, S., Gidalizon, E. (1990). Expert-based method for the evaluation of visual absorption capacity of the landscape. Journal of Environmental Management, 30(3), 251-263. https://doi.org/10.1016/0301-4797(90)90005-H

Anderson, LR., Bennetts, R., Chandler, G., Galliano, S., Holcomb, D., Neville, B. (1976). Visual absorption capability for forest landscapes USDA Forest Service. Klamath National Forest, Yreka, California.

Andrejczuk, W. (2010). Krajobraz a turystyka: aspekt konceptualny (Landscape and tourism: conceptual aspect). Prace Komisji Krajobrazu Kulturowego PTG, 14, 15-25.

Badora, K., Nita, J. (2018). Problemy regionalizacji fizycznogeograficznej pogranicza gór, wyżyn i nizin na przykładzie Płaskowyżu Głubczyckiego i Kotliny Raciborskiej (Problems of physico-geographical 
regionalization of the borderland of the mountains, highlands and lowlands on the example of the Głubczycki Plateau and the Racibórz Basin). Prace Geografczne, 266, 97-108.

http://hdl.handle.net/20.500.12128/7541

Balon, J., Jodłowski, M., Krąż, P. (2018). Mikroregiony fizycznogeograficzne Tatr Zachodnich (Physico-geographical microregions of the Western Tatras). Prace Geograficzne, 91(2), 143-170.

Baranowska-Janota, M., Korzeniak, G. (1991). Zasady turystycznego użytkowania i ochrony parków krajobrazowych (Principles of tourist use and protection of landscape parks). Kraków: Instytut Gospodarki przestrzennej i komunalnej.

Baranowska-Janota, M., Kozłowski, J. (1984). Krańcowe progi przyrodnicze w rozwoju turystyki (Limit thresholds in nature tourism development.). Warszawa: Instytut Kształtowania Środowiska.

Barański, M. (2007). Beskid Śląski - przewodnik (Silesian Beskids - guidebook). Pruszków: Oficyna Wydawnicza Rewasz.

Baretje, R., Defert, P. (1972). Aspects economiques du tourisme. Paris: Editions Berger-Lavrault. https://doi.org/10.2307/1530848

Barker, M.L. (1982). Traditional landscape and mass tourism in the Alps. Geographical Review, 72(4), 395-415. https://doi.org/10.2307/214593

Bartkowski, T. (1972). O pojęciu zasobów-użytków środowiska geograficznego i metodyce ich mierzenia (On the concept of resources of the geographical environment and the methodology for measuring them). Przeglad Geograficzny, 44(1), 31-61.

Bertolo, F. (2000). Catchment delineation and characterisation. Catchment Characterisation and Modelling. EuroLandscape Project. Space Applications Institute. Joint Research Centre Ispra (Va), Italy. Retrieved from http://agrienv.jrc.it/publications/pdfs/CatchRev.pdf [10 May 2018].

Bodoque, J.M., Ballesteros-Cánovas, J.A., Rubiales, J.M., Perucha, M.A., Nadal-Romero, E., Stoffel, M. (2017). Quantifying soil erosion from hiking trail in a protected natural area in the Spanish Pyrenees. Land Degradation and Development. 28, 2255-2267. https://doi.org/10.1002/Idr.2755

Bogucka, A. (2010). Ocena zagospodarowania turystyczno-rekreacyjnego Puszczy Knyszyńskiej (The evaluation of tourist-recreational development of Knyszyńska Forest). Ekonomia i Zarzaqdzanie, 2(3), 77-92.

Boori, M.S., Voženílek, V., Choudhary, K. (2015). Land use/cover disturbance due to tourism in Jeseníky Mountain, Czech Republic: A remote sensing and GIS based approach. The Egyptian Journal of Remote Sensing and Space Science, 18(1), 17-26. https://doi.org/10.1016/j.ejrs.2014.12.002

Buckley, R., Pannell, J. (1990). Environmental impacts of tourism and recreation in national parks and conservation reserves. Journal of Tourism Studies, 1(1), 24-32.

Buckly, R. (2004). Environmental Impacts of Ecotourism. Australia: Griffith University. https://doi.org/10.1079/9780851998107.0000

Burns, P. (2004). Tourism planning: A third way? Annals of Tourism Research, 31(1), 24-43. https://doi.org/10.1016/j.annals.2003.08.001

Butler, R.W. (1980). The concept of tourism area cycle of evolution: Implications for management of resources. Canadian Geographer, 24(1), 5-16. https://doi.org/10.1111/j.1541-0064.1980.tb00970.x

Butler, R.W. (1996). The concept of carrying capacity for tourism destinations: Dead or merely buried? Progress in Tourism and Hospitality Research, 2(3-4). https://doi.org/10.1002/pth.6070020309

Butler, R.W. (2019). Tourism carrying capacity research: A perspective article. Tourism Review, 75(1), 207-211. https://doi.org/10.1108/tr-05-2019-0194.

Chmielewski, T.J. (2012). Systemy krajobrazowe. Struktura - funkcjonowanie - planowanie (Landscape systems. Structure - functioning - planning). Warszawa: Wydawnictwo Naukowe PWN.

Chmielewski, T., Śleszyński, P., Chmielewski, S., Kułak, A. (2018), Ekologiczne i fizjonomiczne koszty bezładu przestrzennego. (Ecological and physiognomic costs of spatial disorder). Prace Geograficzne, 264, Instytut Geografii i Przestrzennego Zagospodarowania PAN, Warszawa. 
Coccossis, H., Mexa, A. (2004). The challenge of tourism carrying capacity assessment: Theory and practice (new directions in tourism analysis). Aldershot: Ashgate.

Cohen, E. (1978). The impact of tourism on the physical environment. Annals of Tourism Research, 5(2), 215-237. https://doi.org/10.1016/0160-7383(78)90221-9

Duffy, R. (2014). Nature-based tourism and neoliberalism: Concealing contradictions. Tourism Geographies, 17(4), 529-543. https://doi.org/10.1080/14616688.2015.1053972

Faracik, R., Kurek, Wł., Mika, M., Pawlusiński, R. (2009). Turystyka w Karpatach Polskich w świetle współczesnych kierunków rozwoju. In B. Domański, W. Kurek (Eds.) Gospodarka i przestrzeń. Prace dedykowane Profesor Danucie Ptaszyckiej-Jackowskiej (pp. 77-97), IGiGP UJ, Kraków.

Forsyth, A. (2003). Measuring density: Working definitions for residential density and building Intensity. Design Center for American Urban Landscape, Deign brief, 9(1), 2-8.

Giedych, R. (2016). Ocena wizualnego wpływu przedsięwzięć na krajobraz - nowe wyzwanie dla ocen środowiskowych (Assessment of the visual impact of the investment on the landscape - a new challenge for environmental assessments). Przestrzeń i Forma, 26, 105-114. https://doi.org/10.21005/pif.2016.26.C-03

Gkoltsiou, K., Terkenli, T.S. (2008). Landscape indicators: A promising tool for analysis of tourist landscape structure. International Conference Studying, Modelling and Sense Making of Planet earth, Myytilene, Lesvos, Greece. Retrieved from http://www.academia.edu/download/32312289/A10ID186_1_.pdf

Gkoltsiou, K., Terkenli, T.S. (2012). An interdisciplinary analysis of tourist landscape structure. Tourismos: An International Multidisciplinary Journal of Tourism, 7(2), 145-164.

Gonda-Soroczyńska, E. (2013). Nietypowe połączenie funkcji uzdrowiskowej z funkcja przemysłowa na przykładzie uzdrowiska Ustron (An unusual combination of the health and industrial functions on the example of the Ustron health-resort). Infrastruktura i Ekologia Terenów Wiejskich, 3(11), 31-46.

Gormsen, E. (1997). The impact of tourism on coastal areas. GeoJournal. 42(39), 39-54. https://doi.org/10.1023/A:1006840622450

Gunn, C.A. (1979). Landscape assessment for tourism. In G.H. Elsner, R.C. Smardon, (technical coordinators), Proceedings of our national landscape: A conference on applied techniques for analysis and management of the visual resource (409-414), Berkeley, CA: Pacific Southwest Forest and Range.

Gunn, C.A., Var, T. (2002). Tourism planning: Fourth edition: Basics, concepts and cases. New York-London: Routledge.

Hendel, M. (2016). Przydatność wskaźników funkcji turystycznej w ocenie rozwoju turystycznego obszaru na przykładzie gminy Ustroń (Usefulness of tourist function indicators in the assessment of tourist development of the area on the example of the Ustron municipality). Zeszyty Naukowe Politechniki Ślaskiej, Organizacja i Zarzadzanie, 87, 157-170.

Inskeep, E. (1987). Environmental planning for tourism. Annals of Tourism Reasearch, 14(1), 118-135.

International Recommendations for Tourism Statistics. (2008). Retrieved from https://unstats.un.org/unsd/publication/seriesm/seriesm_83rev1e.pdf [16 July 2020]

Jansen-Verbeke, M., McKercher, B. (2013). Reflections on the myth of tourism preserving "traditional" agricultural landscapes. Journal of Resources and Ecology, 4(3), 242-249. https://doi.org/10.5814/j.issn.1674-764x.2013.03.007

Jovanović, S., Ilić, I. (2016). Infrastructure as important deter-minant of tourism development in the countries of south-east Europe. Ecoforum, 5, 1(8), 288-294

Kistowski, M. (2001). Wybrane problemy metodologiczne i terminologiczne opracowań ekofizjograficznych (Selected methodological and terminological problems of ecophysiographic studies). Problemy Ocen Środowiskowych, 3(14), 32-39.

Kondracki, J. (2002). Geografia regionalna Polski (Regional geography of Poland). Warszawa: Wydawnictwo Naukowe PWN. 
Kowalczyk, A., Derek, M. (2010). Zagospodarowanie turystyczne (Tourist development). Warszawa: Wydawnictwo Naukowe PWN.

Krajewski, P., Mastalska-Cetera, B. (2014). Zastosowanie oceny pojemności krajobrazu w planowaniu przestrzennym na obszarach chronionych na przykładzie miejscowości Sulistrowice w gminie Sobótka (The use of landscape capacity assessment in spatial planning of protected areas on the example of Sulistrowice village in Sobótka commune). Problemy Ekologii Krajobrazu, 37, 147-164.

Krzymowska-Kostrowicka, A. (1997). Geoekologia turystyki i wypoczynku (Geoecology of tourism and leisure). Warszawa: Wydawnictwo Naukowe PWN.

Lipski, Cz., Kostuch, R., Ryczek, M. (2005). Charakterystyka hydrologiczna górnej części zlewni Soły na tle warunków fizjograficznych, klimatu i użytkowania (Hydrological characteristics of the upper part of the Soła basin against the background of physiographic conditions, climate and use). Infrastruktura i Ekologia Terenów Wiejskich, 2, 75-82.

Łajczak, A. (1994). Wpływ antropopresji na środowiska abiotyczne kopuły szczytowej Pilska (Impact of anthropopressure on the abiotic environments of the Pilsko peak dome). Polskie Towarzystwo Rozwoju Ziem Górskich, 4, 47-59.

Małek, St., Gawęda, T. (2005). Charakterystyka chemiczna wód powierzchniowych zlewni Potok Dupniański w Beskidzie Śląskim (Chemical characterization of surface waters of the Dupniański Stream catchment in the Silesian Beskids). Sylwan, 2, 29-36.

Mandic, A., Mrnjavac, Ž., Kordić, L. (2018). Tourism infrastructure, recreational facilities and tourism development. Tourism and Hospitality Management 24(1), 1-22. https://doi.org/10.20867/thm.24.1.12

Mapa hydrograficzna Hydrographic map M-34-86-B, M-34-87-A, M-34-74-D, M-34-75-C. (2002). skala 1:50 000, Pryzmat, Częstochowa.

Marsz, A. (1972). Metoda obliczania pojemności rekreacyjnej ośrodków wypoczynkowych na Niżu (The method of calculating the recreational capacity of holiday resorts). Prace Komisji Geograficzno-Geologicznej PTPN, 13(3).

Mika, M. (1997). Drugie domy w Beskidzie Ślaskim (Second homes in the Silesian Beskids). Turyzm, 7(1), 25-42.

Mika, M. (2001). Współczesne przemiany i zagrożenia środowiska przyrodniczego Beskidu Ślaskiego zwiqzane z turystyka (Contemporary changes and threats to the natural environment of the Silesian Beskid related to tourism). Problemy Ekologii Krajobrazu, 10, 742-748.

Mika, M. (2004). Turystyka a przemiany środowiska przyrodniczego Beskidu Ślaskiego. Kraków: Instytut Geografii i Gospodarki Przestrzennej UJ.

Mika, M., Krzesiwo, K., Krzesiwo, P. (2007). Współczesne problemy rozwoju ośrodków narciarskich w Polsce - przykład Szczyrku (Contemporary Problems of the Development of Polish Ski Resorts - Case Study of the Town of Szczyrk). Prace Geograficzne, 117, 63-77.

Molina-Ruiz, J., Martínez-Sánchez, M.J., Pérez-Sirvent, C., Tudela-Serrano, M.L., García Lorenzo, M.L. (2011). Developing and applying a GIS-assisted approach to evaluate visual impact in wind farms. Renewable Energy, 36(3), 1125-1132. https://doi.org/10.1016/j.renene.2010.08.041

Mullins, P. (2009). Tourism urbanization. International Journal of Urban and Regional Research 15(3), 326-342. https://doi.org/10.1111/j.1468-2427.1991.tb00642.x

Myga-Piątek, U. (2006). Krajobraz kulturowy jako walor i produkt turystyczny - problemy oceny i ochrony. Problemy Ekologii Krajobrazu, 28, 201-212.

Myga-Piątek, U. (2011). Koncepcja zrównoważonego rozwoju w turystyce (The concept of sustainable development in tourism). Problemy Ekorozwoju - Problems of Sustainable Development, 6(1), 145-154.

Myga-Piątek, U. (2016). Krajobraz jako autentyk, makieta, hybryda. Rozważania o roli krajobrazu we współczesnej turystyce. Turystyka Kulturowa, 1, 47-63.

Myga-Piątek, U., Jankowski, G. (2009). Wpływ turystyki na środowisko przyrodnicze i krajobraz kulturowy - analiza wybranych przykładów obszarów górskich (Tourism impact on the natural environment and cultural landscape. Analysis of chosen examples of highlands). Problemy Ekologii Krajobrazu, 25, 27-38. 
Najwer, A., Zwoliński, Z. (2014). Semantyka i metodyka oceny georóżnorodności - przegląd i propozycja badawcza (Semantics and geodiversity assessment methods: Review and research proposal). Landform Analysis, 26, 115-127.

Nita, J., Myga-Piatek, U., Absalon, D. (2015). Assessment of the exposure of tourism-related landscape values of the Silesian Beskids based on computer visualization. In M. Luc; U. Somorowska, J.B. Szmańda (Eds.), Landscape Analysis and Planning: Geographical perspectives (pp. 45-58), Cham: Springer International Publishing. https://doi.org/10.1007/978-3-319-13527-4

Okrasiński, K. (2012). "Siedem Dolin" - rajd samorządowców po przepisach o ochronie przyrody (Seven Valleys" - a rally of local government officials following the nature protection regulations). Dzikie Życie, 3/213, Pracownia na Rzecz Wszystkich Istot.

O'Reilly, A.M. (1986). Tourism carrying capacity: Concept and issues. Tourism Management, 7(4), 254-258.

Ozimek, P., Tarko, J., Łabędź, P. (2010). Cyfrowe modele analizy krajobrazu bazujące na cyfrowych modelach terenu systemów informacji przestrzennej (Digital models of landscape analyses based on GIS digital terrain models). Prace Komisji Krajobrazu Kulturowego PTG, 14, 342-351.

Partyka, J. (2010). Udostępnianie parków narodowych w Polsce a krajobraz (Availability of Poland's national parks for tourism and the landscape). Prace Komisji Krajobrazu Kulturowego PTG, 14, 252-263.

Pawlikowska-Piechotka, A. (2008). Zagospodarowanie turystyczne i rekreacyjne. Gdynia: Novae Res.

Pawłowski, A. (2009). Rewolucja rozwoju zrównoważonego (The sustainable development revolution). Problemy ekorozwoju. Problems of Sustainable Development, 4(1), 65-79.

Petrikovičová, L., Krogmann, A., Fialová, D., Svorad, A. (2019). Intensive tourist-related urbanisation impacts on a mountain village: The case study of Vel'ká Lomnica in Slovakia. Geographia Polonica, 92(4), 395-408. https://doi.org/10.7163/GPol.0155

Petryszyn, J., Zuzańska-Żyśko, E. (2009). Etapy rozwoju gospodarczego i przestrzennego Ustronia. Geographia. Studia et Dissertationes, 31, 127-145.

Pietrzak, M. (2010). Krajobraz rekreacyjny - istota, treść i zakres pojęcia (Recreational landscape - essence, content and scope of the term). Problemy Ekologii Krajobrazu, 27, 321-326.

Płocka, J. (2005). Wybrane zagadnienia z zagospodarowania turystycznego. Toruń: Centrum Kształcenia Ustawicznego.

Płocka, J. (2009). Zagospodarowanie turystyczne powiatu golubsko-dobrzyńskiego jako niezbędny element turystyki aktywnej (Tourist development in the District of Golub-Dobrzyń as the indispensable element of active tourism). Problemy Ekologii Krajobrazu, 25, 125-137.

Ptaszycka-Jackowska, D., Baranowska-Janota, M. (1998). Przyrodnicze obszary chronione. Możliwości użytkowania. Warszawa: Instytut Gospodarki Przestrzennej i Komunalnej.

Raina, A.K. (2005). Ecology wildlife and tourism development. Principles, practices and strategies. New Delhi: Sarup \& Sons.

Rixen, Ch., Rolando, A. (2013). The impacts of skiing and related winter recreational activities on mountain environments. Bentham Science Publishers. https://doi.org/10.2174/97816080548861130101

Roczniki statystyczne GUS. Turystyczne obiekty noclegowe na obszarach nadmorskich w sezonie wakacyjnym 2018 r. (Statistical Yearbooks of the Central Statistical Office. Tourist accommodation infrastructure in coastal areas during the 2018 holiday season.)

Rogalewski, O. (1974). Zagospodarowanie turystyczne. Warszawa: Wydawnictwa Szkolne i Pedagogiczne.

Rygiel, P. (2007). Odporność wizualna krajobrazu - zastosowanie w planowaniu przestrzennym. Czasopismo Techniczne. Architektura, 104(5-A), 257-258.

Simón, F.J.G., Narangajavana, Y., Marqués, D.P. (2004). Carrying capacity in the tourism industry: A case study of Hengistbury Head. Annals of Tourism Research, 25(2), 275-283.

https://doi.org/10.1016/s0261-5177(03)00089-x 
Ski area plans threaten Europe's last untouched forests. (2009). Retrieved from https://wwf.panda.org/wwf_news/?184562/Ski-area-plans-threaten-Europes-last-untouched-forests [16 July 2020].

Solon, J., Borzyszkowski, J., Bidłasik, M., Richling, A., Badora, K., Balon, J., Brzezińska-Wójcik, T., Chabudziński, Ł., Dobrowolski, R., Grzegorczyk, I., Jodłowski, M., Kistowski, M., Kot, R., Krq̨ż, P., Lechnio, P., Macias, A., Majchrowska, A., Malinowska, E, Migoń, P., Myga-Piątek, U., Nita, J., Papińska, E., Rodzik, J., Strzyż, M., Terpiłowski, S., Ziaja, W. (2018). Physico-geographical mesoregions of Poland: Verification and adjustment of boundaries on the basis of contemporary spatial data. Geographia Polonica, 91(2), 143-170. https://doi.org/10.7163/gpol.0115

Sołtys, J. (2009). Zagospodarowanie turystyczne obszarów górskich a krajobraz - wybrane problemy (Tourist development of mountain areas and landscape - chosen problems). Czasopismo Techniczne. Architektura, 106(2-A), 125-130.

Stalski, M. (1986). Protection of the human environment and tourism: Possibilities of co-operation of two spheres of human activity. Geographia Polonica, 52, 295-306.

Stoffelen, A., Vanesste, D. (2015). An integrative geotourism approach: Bridging conflicts in tourism landscape research. Tourism Geographies, 17(4), 544-560. https://doi.org/10.1080/14616688.2015.1053973

Sun, D., Walsh, D. (1998). Review of studies on environmental impacts of recreation and tourism in Australia. Journal of Environmental Management, 53(4), 323-338. https://doi.org/10.1006/jema.1998.0200

Szromek, A. (2012). Wskaźniki funkcji turystycznej. Koncepcja wskaźnika funkcji turystycznej i uzdrowiskowej. Gliwice: Wydawnictwo Politechniki Śląskiej.

Ślusarczyk, R., Bożek, G. (2006). Pilsko symbolem ignorancji człowieka wobec przyrody i prawa. Dzikie życie 2/140, Pracownia na Rzecz Wszystkich Istot.

Terkenli, T.S. (2002). Landscapes of tourism: towards a global cultural economy of space?. Tourism Geographies 4(3), 227-254. https://doi.org/10.1080/14616680210147409

Tesler, M., Clark, T.A. (2019). The impact of bouldering on rock-associated vegetation. Biological Conservation, 204(B), 426-433. https://doi.org/10.1016/j.biocon.2016.10.004

UNWTO (1981). Saturation of Tourist Destinations: Report of the Secretary General. Madrid: World Tourism Organization. Retrieved from https://www.e-unwto.org/doi/pdf/10.18111/unwtogad.1981.1.un406362r557g40k [20 july 2020]

Ustawa z dnia 27 marca 2003 r. o planowaniu i zagospodarowaniu przestrzennym (Dz. U. z 2017 r. poz. 1073) (Act of 27 March 2003 on spatial planning and development).

Visual Impact Assessment Guidebook (1995). Forest Service, British Columbia.

Warszyńska, J. (2006). Turystyka zrównoważona na obszarze Beskidów Zachodnich: studium uwarunkowań i barier rozwoju (Sustainable tourism in the Western Beskids: study of conditions and barriers of development). Kraków: Instytut Gospodarki Surowcami Mineralnymi i Energią Polskiej Akademii Nauk.

Warszyńska, J., Jackowski, A. (1978). Podstawy geografii turyzmu. Warszawa: Wydawnictwo Naukowe PWN.

Włodarczyk, B. (2011). Procesy kształtujące przestrzeń turystycznq. Turyzm, 21(1-2), 59-66.

Włodarczyk, B. (2014). Przestrzeń w turystyce, turystyka w przestrzeni - o potrzebie definicji, delimitacji $i$ klasyfikacji. (Space in tourism, tourism in space - about the need for definition, delimitation and classification). Turyzm, 24(1), 25-35.

Wyrzykowski, J. (1991). Ocena krajobrazu Polski w aspekcie fizjonomicznym na potrzeby turystyki (Assessment of the Polish landscape for tourism in the physiognomic aspect). Wrocław: Uniwersytet Wrocławski, Instytut Geografii. 
Zamek na obszarze Natura 2000? Ekolodzy nie maja nic przeciwko, (A castle in the Natura 2000 area? Environmentalists don't mind). (2018). Retrieved from www.ekologia.pl/wiadomosci/srodowisko/zamek-na-obszarze-natura-2000-ekolodzy-nie-maja-nic-przeciwko,24148.html. [5 January 2020].

Zolotov, DV., Chernykh, D.V. (2015). Landscape-basin approach to the study of floristic diversity (heterogeneous cathments of steppe and forest-steppe zones of Altai Krai, Russia, a case study). Acta Biologica Universitatis Daugavpiliensis, 15(2), 135-144.

Żemła, M., Żemła-Siesicka, A. (2010). Rola krajobrazu w kształtowaniu konkurencyjności obszarów recepcji turystycznej (The role of landscape in shaping the competitiveness of tourist reception areas). Turystyka i Hotelarstwo, 16, 111-127.

Żemła-Siesicka, A. (2017). Delimitacja pól podstawowych mezoregionu Beskid Śląski na potrzeby badań przestrzennych infrastruktury turystycznej (Delimitation of basic fields of mezoregion of Silesian Beskid to the purpose of spatial researches of tourist infrastructure). Prace Komisji Krajobrazu Kulturowego PTG, 37, 127-140. 